\title{
The prevalence of hepatitis $A$ in children in British Columbia
}

\author{
Jan J Ochnio $M D P h D^{1}$, David W Scheifele $M D^{1}$, Murray Fyfe $M D^{2}$, Mark Bigham $M D^{3}$, David Bowering $M D^{4}$, \\ Paul Martiquet $\mathrm{MD}^{5}$, Margaret $\mathrm{Ho} \mathrm{BSc}^{1}$, Douglas $\mathrm{N}$ Talling $\mathrm{BSc}^{1}$
}

JJ Ochnio, DW Scheifele, M Fyfe, et al. The prevalence of hepatitis $\mathrm{A}$ in children in British Columbia. Can J Infect Dis Med Microbiol 2005;16(3):175-179.

BACKGROUND: The risk of hepatitis A virus (HAV) infection during childhood is difficult to estimate without population serosurveys because HAV-related symptoms are often mild at this age. Few serosurveys have been conducted in Canada. The present study surveyed teenagers in two nonurban regions of British Columbia where the historical rate of reported HAV either exceeded (region A) or was less than (region B) the historical provincial rate.

METHODS: A point prevalence survey of salivary HAV-specific immunoglobulin $\mathrm{G}$ was conducted in high schools among grade 9 students in regions $\mathrm{A}$ and $\mathrm{B}$. A questionnaire was used to gather sociodemographic data. The survey was extended to grade 1 and grade 5 students in community 1 of region B. Associations between risk factors and prior infection were evaluated by logistic regression. RESULTS: Eight hundred eleven grade 9 students were tested. Antibody to HAV was detected in $4.7 \%$ of students in region A (95\% CI $2.9 \%$ to $7.2 \%$ ) and $9.6 \%$ of students in region B $(95 \% \mathrm{CI}$ $6.9 \%$ to $12.9 \%$ ). The region B figure reflected HAV antibody prevalence rates of $19.5 \%$ in community 1 and $2.5 \%$ in the remainder of the region. Younger students in community 1 had low HAV antibody to HAV prevalence rates (3.9\% for grade 1 and $3.1 \%$ for grade 5 ), and positive tests in this community were associated with a particular school, foreign travel and brief residence. The risk factors for HAV infection in grade 9 students were not determined.

CONCLUSIONS: Children in nonurban areas of British Columbia are generally at low risk of HAV infection during the first decade of life regardless of the reported population rates, thereby permitting the consideration of school-based HAV immunization programs.

Key Words: Children; Hepatitis A; Prevalence; Saliva

Cenerally, Canadians who do not travel to hepatitis AJendemic areas are considered to be at low risk for this infection (1), although estimates of hepatitis A incidence in Canada indicate substantial rate diversity (2). Based on notifications of new cases, incidence rates differ considerably among provinces and smaller geographical regions and communities $(2,3)$. This apparent diversity has substantial implications for the most efficient use of inactivated hepatitis A vaccines. In the United States (US), routine early childhood hepatitis A

\section{La prévalence d'hépatite $\mathrm{A}$ chez des enfants de la Colombie-Britannique}

HISTORIQUE : Le risque d'infection au virus de l'hépatite A (VHA) pendant l'enfance est difficile à évaluer sans relevé sérologique de population, parce que les symptômes reliés au VHA sont souvent bénins à cet âge. Peu de relevés sérologiques ont été obtenus au Canada. La présente étude a permis de relever les adolescents de deux régions non urbaines de la Colombie-Britannique, où le taux historique de VHA déclaré était supérieur (région A) ou inférieur (région B) au taux provincial historique.

MÉTHODOLOGIE : Un relevé de prévalence ponctuelle de l'immunoglobuline G salivaire propre au VHA a été effectué chez les élèves de neuvième année des écoles secondaires des régions $\mathrm{A}$ et $\mathrm{B}$. Le relevé a été étendu aux élèves de première année et de cinquième année de la collectivité 1 de la région $B$. L'association entre les facteurs de risque et une infection antérieure a été évaluée par régression logistique.

RÉSULTATS : Huit cent onze élèves de neuvième année ont été testés. Des anticorps au VHA ont été décelés chez 4,7\% des élèves de la région $\mathrm{A}(95 \% \mathrm{IC} 2,9 \%$ à 7,2 \%) et chez $9,6 \%$ des élèves de la région $\mathrm{B}$ (95\% IC 6,9 \% à 12,9\%). Les chiffres de la région B reflètent des taux (d'anticorps à la prévalence de VHA) de 19,5\% dans la collectivité 1 et de $2,5 \%$ dans le reste de la région. Les élèves plus jeunes de la collectivité 1 présentaient peu d'anticorps aux taux de prévalence du VHA (3,9\% en première année et 3,1 \% en cinquième année), et les tests positifs dans cette collectivité s'associaient à une école en particulier, à des voyages à l'étranger et à une brève résidence. Les facteurs de risque d'infection au VHA chez les élèves de neuvième année étaient indéterminés.

CONCLUSIONS : En général, les enfants des zones non urbaines de la Colombie-Britannique sont peu vulnérables à l'infection au VHA pendant leur première décennie de vie, quels que soient les taux déclarés dans la population, ce qui permet d'envisager des programmes de vaccination contre le VHA en milieu scolaire.

immunization programs have been adopted in states with incidence rates consistently exceeding the historical national average (4). In Canada, however, hepatitis $A$ vaccines are still targeted selectively at those with increased risk of infection or serious complications (5).

Among Canadian provinces, British Columbia has historically reported the highest rates of hepatitis A virus (HAV) infection $(2,6)$. Within British Columbia, the highest rates have been reported in metropolitan Vancouver, where the

${ }^{1}$ Vaccine Evaluation Centre, BC Children's Hospital and the University of British Columbia; ${ }^{2}$ University of British Columbia Centre for Disease

Control; ${ }^{3}$ Canadian Blood Services, Vancouver; ${ }^{4}$ Northern Health Authority, Prince George; ${ }^{5}$ Vancouver Coastal Health Authority,

Vancouver, British Columbia

Correspondence: Dr Jan J Ochnio, Vaccine Evaluation Centre, Room 317A, 950 West 28th Avenue, Vancouver, British Columbia V5Z 4 H4.

Telephone 604-875-3654, fax 604-875-2496, e-mail jochnio@interchange.ubc.ca

Received for publication July 21, 2004. Accepted November 22, 2004 
endemic and periodically epidemic spread of hepatitis A infection has been identified in illicit drug users, men who have sex with men, and sex trade workers (7-9). A survey of HAV antibodies in children 11 to 12 years of age attending schools in Vancouver in 1996 (10) revealed a low cumulative risk (3\%) for those born and raised in Canada, suggesting little crosscirculation of HAV between children and the adult populations at risk in this urban setting. However, the epidemiology of HAV infection may differ in rural settings (11), where children may be more involved in disease transmission. To explore the risk of HAV infection for children in less urbanized areas of British Columbia, the authors chose two regions for the present study. Both regions are predominantly rural, with towns and villages separated by farmland and forest. Region A generally reported rates of HAV infection above the provincial average during the past decade (often second only to Vancouver), while region $\mathrm{B}$ generally reported rates below the provincial average (with no cases reported in 2000/2001). To determine whether children are important in virus transmission in these regions, the authors used a noninvasive antibody to HAV (anti-HAV) detection method in saliva (12) to assess prior exposure to HAV in a sample of school children.

\section{METHODS}

\section{Recruitment and study population}

The authors surveyed grade 9 students (14 to 15 years of age) attending public high schools in regions A and B. Twenty of 21 schools in the two regions were sampled between September and November of 2000. The invitation to participate in the study was extended to all students attending a randomly selected classroom. In larger schools, more than one classroom was invited to participate to maintain approximately $25 \%$ representation from each school's grade 9 population.

When preliminary results indicated that prior infection was much more common in one particular community in region $\mathrm{B}$ (community 1) than in other areas, an extended survey was conducted among grade 1 (five to six years of age) and grade 5 (nine to 10 years of age) students in this community later in the same school year. All 13 primary schools within the catchment area of the four high schools serving community 1 were sampled. Here, too, the objective was to sample approximately $25 \%$ of the students, with whole classes serving as the sampling unit.

Assuming an anti-HAV prevalence among grade 9 students of approximately $10 \%$, the authors determined that a sample size of 400 individuals per health region would have a $95 \%$ probability of estimating the actual value within $\pm 3 \%(\alpha=0.05)$. For the follow-up survey, assuming an anti-HAV prevalence of approximately 20\% among grade 5 and grade 1 students (similar to grade 9 students in this community), the authors determined that a sample of 200 students per grade would have a $95 \%$ probability of estimating the actual value in each grade within $\pm 5.5 \%(\alpha=0.05)$.

\section{Enrollment procedures}

Following study approval by the relevant school boards, the principals of participating schools arranged for the distribution of notices describing the study to the parents/guardians of students in the selected classes. In primary schools, each notice was accompanied by a consent form and a questionnaire to be completed by parents on behalf of the student. Grade 9 students consented on their own but their parents had an opportunity to provide advice. On a prearranged day, the study nurse visited the classroom, showed the participating students how to collect salivary specimens, and supervised the specimen collection. Nurses also helped grade 9 participants complete their questionnaires. There were no exclusion criteria apart from the inability to provide informed consent.

\section{Detection of HAV-specific immunoglobulin G}

Saliva collection was facilitated by use of Salivette (Sarstedt, Germany) or OmniSal (Saliva Diagnostic Systems, USA) devices. Saliva specimens were refrigerated immediately after collection. Recovered saliva was aliquoted and frozen at $-70^{\circ} \mathrm{C}$ within $72 \mathrm{~h}$ of collection. All specimens were screened for the presence of a sufficient amount of total immunoglobulin (Ig) G (10). HAV-specific antibodies were detected using an ultrasensitive salivary assay for anti-HAV of IgG class (12). When compared with blood tests, this salivary assay demonstrated $99 \%$ sensitivity and specificity in differentiating between immune and susceptible individuals (12).

\section{Gathering demographic data}

Basic demographic information about the participants was obtained using a one-page, self-administered questionnaire. This questionnaire was based on a similar instrument used successfully in previous surveys $(10,13)$. The questionnaire contained questions on sex, birthdate, birthplace, duration of residence in the region, source of drinking water and size of the student's household. Because the questionnaire used for grade 1 and grade 5 students was to be completed by their parents/guardians, the questions were rephrased and supplemented by questions about previous hepatitis A vaccination, household exposure to hepatitis $\mathrm{A}$, foreign travel and geographical area of residence.

\section{Statistical analysis}

Personal data and test results were entered into an electronic database using dual data entry and preprogrammed consistency checks to minimize transcription errors.

Proportional data were compared using $\chi^{2}$ and Fisher's exact tests (two sided). The associations among potential risk factors, demographic characteristics and past infection with HAV were evaluated using backward logistic regression. This analysis was limited to grade 1 and grade 5 students. Goodness-of-fit statistics were examined to determine the appropriateness of the final model.

\section{Ethical approval}

The study and questionnaires were reviewed and approved by the Clinical Research Ethics Board of the University of British Columbia (Vancouver, British Columbia).

\section{RESULTS}

\section{Grade 9 survey}

Four hundred five students in region A and 406 students in region B participated, representing $35 \%$ and $23 \%$ of registered grade 9 students in the regions, respectively. All of the students provided a sufficient saliva sample and a brief personal history. At the participating school level, samples ranged from $18.9 \%$ to $50.0 \%$ of eligible students. The participation rate among invited students was estimated to exceed $90 \%$.

Anti-HAV IgG was detected in 58 of 811 students, for an overall prevalence of $7.15 \%$ (95\% CI $5.5 \%$ to $9.2 \%$ ). Anti-HAV IgG prevalence was, however, twice as high in region B students $(9.6 \%, 95 \%$ CI $6.9 \%$ to $12.9 \%)$ than in region A students (4.7\%, 95\% CI 2.9\% to $7.2 \%)$. The higher prevalence in region $\mathrm{B}$ resulted from an exceptionally high rate of $19.5 \%$ (33/169) among students in four high schools located in community 1 (population 51,500). The prevalence rate in 
TABLE 1

Prevalence of antibody to hepatitis A virus (anti-HAV) immunoglobulin G among grade 9 study participants in regions $A$ and $B$, according to school attended

\begin{tabular}{|c|c|c|c|c|c|c|c|}
\hline \multicolumn{4}{|c|}{ Region A } & \multicolumn{4}{|c|}{ Region B } \\
\hline School & $\begin{array}{l}\text { Students } \\
\text { tested (n) }\end{array}$ & $\begin{array}{l}\text { Anti-HAV- } \\
\text { positive }\end{array}$ & $\begin{array}{c}\text { Anti-HAV- } \\
\text { positive (\%) }\end{array}$ & School & $\begin{array}{l}\text { Students } \\
\text { tested (n) }\end{array}$ & $\begin{array}{l}\text { Anti-HAV- } \\
\text { positive }\end{array}$ & $\begin{array}{c}\text { Anti-HAV- } \\
\text { positive (\%) }\end{array}$ \\
\hline$A$ & 27 & 3 & 11.1 & $J^{*}$ & 40 & 12 & 30.0 \\
\hline$B$ & 41 & 4 & 9.8 & $\mathrm{~K}^{*}$ & 38 & 8 & 21.1 \\
\hline C & 31 & 3 & 9.7 & $L^{*}$ & 37 & 6 & 16.2 \\
\hline D & 26 & 2 & 7.7 & $M^{*}$ & 54 & 7 & 13.0 \\
\hline$E$ & 61 & 3 & 4.9 & $\mathrm{~N}$ & 30 & 2 & 6.7 \\
\hline $\mathrm{F}$ & 75 & 2 & 2.7 & O & 20 & 1 & 5.0 \\
\hline G & 64 & 1 & 1.6 & $\mathrm{P}$ & 43 & 2 & 4.7 \\
\hline $\mathrm{H}$ & 67 & 1 & 1.5 & Q & 45 & 1 & 2.2 \\
\hline \multirow[t]{3}{*}{ I } & 13 & 0 & 0 & $\mathrm{R}$ & 28 & 0 & 0 \\
\hline & & & & $S$ & 23 & 0 & 0 \\
\hline & & & & $\mathrm{T}$ & 48 & 0 & 0 \\
\hline Total & 405 & 19 & $4.7 \%$ & Total & 406 & 39 & $9.6 \%$ \\
\hline
\end{tabular}

*Schools serving community 1. Identifiers were assigned posthoc, for convenient presentation

the other communities of region B was $2.5 \%(6 / 237)$. The distribution of positive cases in both regions (including community 1) according to school is presented in Table 1 . The prevalence of anti-HAV IgG was almost identical in female and male students in each of the regions and in community 1.

Only $31(4 \%)$ of 811 tested students were born outside of Canada; of these, four $(12.9 \%)$ tested positive for anti-HAV IgG. Of the 169 students tested in community 1, only five were foreign-born; of these five students, two tested positive. Community 1 students within region B had lived in the area for an average of 10.2 years, which was similar to the duration for students in region $\mathrm{A}$ and the remainder of region $\mathrm{B}$ (10.2 and 10.8 years, respectively). The median size of students' households in region A (4.46 members), community 1 in region $B$ (4.34 members), and the remainder of students in region B (4.37 members) was also similar. Univariate analyses found the following factors to be unassociated with a positive test: duration of residence in the area; drinking water source; and household size. No additional information was obtained from these students.

Extended surveys in community 1

Two hundred fifteen grade 1 students and 261 grade 5 students participated, representing $37.8 \%$ and $39.1 \%$ of the total grade 1 and grade 5 enrollment in the 13 sampled schools, respectively. All subjects provided an adequate saliva sample and returned at least a partially completed questionnaire. At the individual school level, study participants represented $19 \%$ to $45 \%$ and $30 \%$ to $59 \%$ of the grade 1 and grade 5 enrollment, respectively.

In total, 22 students tested positive for anti-HAV IgG, for an overall prevalence rate of $4.6 \%$. However, 10 students (six of whom were positive for HAV-specific antibody) were reported as being vaccinated for hepatitis A previously. Because the validity of these reports could not be verified, all 10 individuals were removed from further analysis. Anti-HAV IgG was detected in 16 of the 466 remaining students, for a rate of $3.4 \%$ (95\% CI $2.0 \%$ to $5.5 \%)$, and further analysis revealed that the test was positive in eight of 208 grade 1 students $(3.9 \%, 95 \%$ CI $1.7 \%$ to $7.4 \%)$ and eight of 258 grade 5 students $(3.1 \%$, $95 \%$ CI $1.4 \%$ to $6.0 \%)$.
The vast majority of participating grade 1 and grade 5 students $(97.4 \%$ ) was born in Canada. Of the 12 individuals born elsewhere, six originated in countries with an increased risk for HAV infection; of these six students, only one was positive for HAV-specific IgG.

Fourteen students reported past HAV infection in their family but only one tested positive. The validity of these reports could not be confirmed. Because the majority of reported infections among family members took place before these students were born, the potential value of this information was not evaluated further.

The distribution of positive cases according to school and grade for the 13 primary schools sampled in community 1 is summarized in Table 2. Four schools had no positive cases and six schools had only one positive case. Schools 8 and 10 had two positive cases each, corresponding to rates of approximately $6 \%$ and $4 \%$, respectively, in grade 1 and grade 5 students. Of the 38 students from school 12, six tested positive, indicating a prevalence rate of $15.8 \%$ (95\% CI $6.0 \%$ to $31.3 \%)$. The positivity rate for students in school $12(15.8 \%)$ was significantly higher than the rate for students in the other 12 schools (2.4\%) (95\% CI $1.2 \%$ to $4.4 \%, \mathrm{P}<0.0001)$.

Univariate analysis indicated that the duration of residence in community 1 was not associated with a higher anti-HAV prevalence rate, with the exception of individuals who reported moving into the area in the previous two years. Of 55 such individuals, five $(9.1 \%)$ tested positive for anti-HAV IgG; this positivity rate was three times higher than the rate for students who had lived in the area for more than two years $(2.7 \%)$. The difference was more than fivefold for grade 1 students that had lived in the area for less than two years $(12.1 \%)$ versus more than two years $(2.3 \%)(\mathrm{P}=0.02)$. Among grade 5 students, the rate was similar for those who had lived in the area for less than two years $(4.6 \%)$ versus more than two years $(3.0 \%)(\mathrm{P}=0.74)$.

Drinking water source was evaluated as a potential predictor for a positive HAV test but a large proportion of participants did not answer this question properly. Ten of the 245 students $(4.1 \%)$ who indicated "town pipes" as a source of drinking water tested positive. None of the 26 individuals indicating a private well as main source of drinking water tested positive. 
TABLE 2

Positive antibody to hepatitis A virus (anti-HAV) cases among nonvaccinated grade 1 and grade 5 study participants in community 1 , according to school attended

\begin{tabular}{|c|c|c|c|c|c|c|}
\hline \multirow[b]{2}{*}{$\begin{array}{l}\text { School } \\
\text { number }\end{array}$} & \multicolumn{2}{|c|}{$\begin{array}{c}\text { Grade } 1 \text { study } \\
\text { participants }\end{array}$} & \multicolumn{2}{|c|}{$\begin{array}{c}\text { Grade } 5 \text { study } \\
\text { participants }\end{array}$} & \multicolumn{2}{|c|}{ Totals } \\
\hline & Tested & $\begin{array}{l}\text { Anti-HAV- } \\
\text { positive }\end{array}$ & Tested & $\begin{array}{l}\text { Anti-HAV- } \\
\text { positive }\end{array}$ & Tested & $\begin{array}{l}\text { Anti-HAV- } \\
\text { positive }\end{array}$ \\
\hline 1 & 9 & 0 & 11 & 0 & 20 & 0 \\
\hline 2 & 31 & 1 & 20 & 0 & 51 & 1 \\
\hline 3 & 15 & 0 & 17 & 1 & 32 & 1 \\
\hline 4 & 20 & 0 & 22 & 0 & 42 & 0 \\
\hline 5 & 13 & 0 & 22 & 1 & 35 & 1 \\
\hline 6 & 9 & 0 & 23 & 0 & 32 & 0 \\
\hline 7 & 14 & 1 & 20 & 0 & 34 & 1 \\
\hline 8 & 15 & 2 & 19 & 0 & 34 & 2 \\
\hline 9 & 11 & 0 & 19 & 1 & 30 & 1 \\
\hline 10 & 31 & 1 & 22 & 1 & 53 & 2 \\
\hline 11 & 16 & 0 & 18 & 0 & 34 & 0 \\
\hline 12 & 14 & 2 & 24 & 4 & 38 & 6 \\
\hline 13 & 10 & 1 & 21 & 0 & 31 & 1 \\
\hline Total & 208 & 8 & 258 & 8 & 466 & 16 \\
\hline
\end{tabular}

Seventy students (15\%) reported travelling outside of Canada and the US. The prevalence of anti-HAV among students who travelled (six of 70 students [8.6\%]) (95\% CI 3.2\% to $17.7 \%$ ) was more than three times higher than among students who denied foreign travel (10 of 394 students [2.5\%]) (95\% CI $1.2 \%$ to $4.6 \%)(\mathrm{P}=0.11)$. The difference in rates of anti-HAV between students who travelled and those who did not was particularly pronounced in grade 1 (four of 29 [13.8\%] versus four of 177 [2.3\%], respectively, $\mathrm{P}=0.003$ ), while in grade 5 , the difference between these two groups was negligible ( $4.9 \%$ versus $2.8 \%, \mathrm{P}=0.47$ ).

In addition to the risk factors reported in the literature to be associated with HAV infection, such as birth in areas of increased risk, travel to areas of increased risk and household size, the initial explanatory model also included the following factors: sex; age (represented by attendance of grade 1 or 5); source of drinking water; and those demographic characteristics that univariate analyses revealed to be significant, such as migration to community 1 within the past two years, residence in neighbourhood $\mathrm{A}$ and attendance at school 12. Logistic regression identified three independent factors to be significantly associated with increased anti-HAV prevalence; in the final model, attendance at school 12 showed the most pronounced association with a positive HAV test $(\mathrm{P}<0.001)$, followed by a history of travel outside of Canada and the US $(\mathrm{P}=0.006)$ and a history of moving into community 1 within the previous two years $(\mathrm{P}=0.019)$. No significant interactions among the evaluated factors were identified.

\section{DISCUSSION}

The present study was the first to measure the cumulative risk of HAV infection among British Columbian children residing outside of the large metropolitan centres. Our findings indicated that such children are at low risk for this infection during the first decade of life. This was true whether children lived in regions with high or low rates of reported infection relative to the provincial average. Regional rates were based on case notifications, which involved mainly adults.
Testing populations for the presence of HAV-specific antibodies offers more insight into prior exposure to viral antigens than do case notifications $(14,15)$. This is particularly true in children because HAV infection in this age group is likely to be asymptomatic or misdiagnosed (16). To gauge the risk of HAV infection in children in these relatively sparsely populated areas (approximately 75,000 inhabitants each), we chose the format of a school-based point prevalence survey. Targeting high school children meant that class samples would include children from wide areas and that participants could consent for themselves. The detection of prior HAV infection using a painless, saliva-based method (12) facilitated student enrollment and resulted in good participation rates. Nearly all of the schools participated and provided the desired sample of students. Because classes were used as the sampling unit, it was difficult to obtain a uniform $25 \%$ sample of each school, thus explaining the variation in sample size (from 19\% to 50\%) among schools.

The overall prevalence rate of anti-HAV detected in grade 9 students in regions A and B (7.15\%) was almost identical to the rate $(7.1 \%)$ observed previously in grade 6 students in Vancouver (10), and similar to the rate $(6.3 \%)$ reported in Vancouver street youth (13). More than 25\% of Vancouver students were born outside of Canada; this subgroup contained the majority of anti-HAV-positive children (10). In the present study, foreign-born individuals constituted only $4 \%$ of the sample. Among Canadian-born grade 9 students, the rate of past HAV infection in the two health regions $(6.9 \%)$ was higher than the rate $(3 \%)$ recorded in Canadian-born Vancouver students. However, the rates in the present study were driven up by the extraordinarily high anti-HAV prevalence $(19.5 \%)$ in grade 9 students in community 1 of region B. Excluding community 1 students, the detected antibody prevalence in region $\mathrm{A}$ and the remainder of region $\mathrm{B}(3.7 \%)$ was almost identical to the rate in Vancouver.

The extraordinarily high anti-HAV prevalence observed in community 1 prompted extended surveys of younger children. The prevalence of past HAV infection in grade 1 and grade 5 students was relatively low $(3.5 \%)$, suggesting that the mechanism that led to high rates in grade 9 students was unique to the older group. The possibility that grade 9 students were infected in early childhood (more than 11 years earlier) is unlikely because the positivity rate was highest for those who lived in the community for less than five years and lowest for those who lived in the community for more than 11 years (data not presented). Thus, it is likely that most infections happened recently. A small increase in reported cases in the community occurred in 1998, which was believed at the time to be limited to adult illicit drug users. However, it is possible that there was substantial but unrecognized transmission among older children. The present study did not explore risk factors such as street drug use (17) or teen socialization patterns. Little distribution of hepatitis A vaccine has occurred in children in this community, thus precluding immunization as an appreciable source of anti-HAV (18) in our sample.

The extended survey in community 1 included primary school grades, thus providing a neighbourhood by neighbourhood perspective. This community was a microcosm of the region, with one particular school having more positive children than other schools. The school in question is located in a multiethnic neighbourhood, but local officials are unaware of any particular risk factors for HAV infection. More information 
was available for younger students because parents completed their questionnaires. Logistic regression analysis identified recent relocation to community 1 to be associated with a positive anti-HAV test. This result was unexpected, and may indirectly reflect other risk factors such as household crowding (19) or poorer living conditions (20). Analysis also identified travel outside of Canada and the US to be significantly associated with a positive test, especially among the youngest children. A study in Quebec (21) showed foreign travel to be an important risk factor for HAV infection.

Because the present survey included only two health regions, the findings may not be generalizable to other regions or to the province as a whole. Children attending private or religious schools and home-schooled children were not represented in our sample. However, there are few such schools in the two regions and they have limited enrollment. Because we chose not to collect information on ethnic background, the proportion of First Nations children and their contribution to the positivity rate could not be estimated. Some First Nations communities in British Columbia have had epidemics of HAV infection in recent years (22) but neither of the regions studied was affected. The lack of reliable information on prior

\section{REFERENCES}

1. National Advisory Committee on Immunization (NACI). Statement on the prevention of hepatitis A infections. Can Commun Dis Rep 1994;20:133-43.

2. Wu J, Zou S, Giulivi A. Current hepatitis A status in Canada. Can J Infect Dis 2001;12:341-4.

3. BC reportable communicable diseases, annual summary 1998. Vancouver: UBC Centre for Disease Control, 1999:23-5.

4. Prevention of hepatitis A through active or passive immunization Recommendations of the Advisory Committee on Immunization Practices (ACIP). MMWR Recomm Rep 1999;48:1-37.

5. Canadian Immunization Guide, 6th edn. Ottawa: Health Canada, 2002:93-101.

6. Notifiable diseases annual summary. Can Commun Dis Rep 2001;27S6:110.

7. Hepatitis A in Vancouver, British Columbia: An outbreak among homosexual men. B.C. Health and Disease Surveillance 1992;1:71-2.

8. Ng T, Farley JD, Mathias RG, Cook D, Bardsley J, Jin A. Hepatitis A outbreak in British Columbia, 1988-1989. Can Dis Wkly Rep $1989 ; 15: 163-5$

9. Jin A, Bardsley J. Intravenous drug use and hepatitis A: An investigation of an outbreak. Can J Public Health 1990;81:79-81.

10. Ochnio JJ, Scheifele DW, Ho M. Hepatitis A virus infections in urban children - are preventive opportunities being missed? J Infect Dis 1997;176:1610-3.

11. Bell BP, Shapiro CN, Alter MJ, et al. The diverse patterns of hepatitis A epidemiology in the United States - implications for vaccination strategies. J Infect Dis 1998;178:1579-84.

12. Ochnio JJ, Scheifele DW, Ho M, Mitchell LA. New, ultrasensitive enzyme immunoassay for detecting vaccine- and disease-induced hepatitis $A$ virus-specific immunoglobulin $G$ in saliva. J Clin Microbiol 1997;35:98-101. hepatitis A vaccination, particularly among grade 9 students, was another limitation that hampered the accuracy of the present study. Limited information was requested from grade 9 students, precluding extensive risk factor analysis.

\section{SUMMARY}

Our findings indicate that children living in rural areas are not commonly involved in HAV transmission. When combined with our previous report (10) on prevalence of HAV infection in Vancouver children, the data suggest a low risk of HAV infection in children in British Columbia, leaving room for the consideration of provincial immunization programs targeted at older children. The grade 6 provincial hepatitis B immunization program assessed by Dobson et al (23) would provide an ideal platform for a program using a combined hepatitis $\mathrm{A}$ and hepatitis B vaccine (24).

ACKNOWLEDGEMENTS: The authors thank all of the children for participating in the survey and school officials for facilitating the study. The authors are also grateful to study coordinators Jane Macnabb and Carol LaJeunesse for their efforts in organizing and carrying out this survey.

13. Ochnio JJ, Patrick D, Ho M, Talling DN, Dobson SR. Past infection with hepatitis A virus among Vancouver street youth, injection drug users and men who have sex with men: Implications for vaccination programs. CMAJ 2001;165:293-7.

14. Gust ID. Epidemiological patterns of hepatitis A in different parts of the world. Vaccine 1992;10(Suppl 1):S56-8.

15. Koff SR. Seroepidemiology of hepatitis A in the United States. J Infect Dis 1995;171(Suppl 1):S19-23.

16. Forbes A, Williams R. Changing epidemiology and clinical aspects of hepatitis A. Br Med Bull 1990;46:303-18.

17. Franco E, Giambi C, Ialacci R, Coppola RC, Zanetti AR. Risk groups for hepatitis A virus infection. Vaccine 2003;21:2224-33.

18. Van Herck K, Van Damme P. Inactivated hepatitis A vaccineinduced antibodies: Follow-up and estimates of long-term persistence. J Med Virol 2001;63:1-7.

19. Green MS, Zaaide Y. Sibship size as a risk factor for hepatitis A infection. Am J Epidemiol 1989;129:800-5.

20. Szmuness W, Dienstag JL, Purcell RH, Harley EJ, Stevens CE, Wong DC. Distribution of antibody to hepatitis A antigen in urban adult populations. N Engl J Med 1976;295:755-9.

21. De Serres G, Duval B, Shadmani R, et al. Ineffectiveness of the current strategy to prevent hepatitis A in travelers. J Travel Med 2002;9:10-6.

22. Harb J, Lem M, Fyfe M, et al. Hepatitis A in the Northern Interior of British Columbia: An Outbreak Among Members of A First Nations Community. Can Commun Dis Rep 2000;26-19:157-61.

23. Dobson S, Scheifele D, Bell A. Assessment of a universal, schoolbased hepatitis B vaccination program. JAMA 1995;274:1209-13.

24. Dominguez A, Salleras L, Carmona G, Batalla J. Effectiveness of a mass hepatitis A vaccination program in preadolescents. Vaccine 2003;21:698-701. 


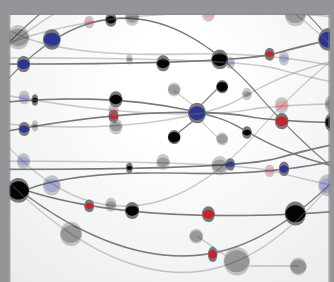

The Scientific World Journal
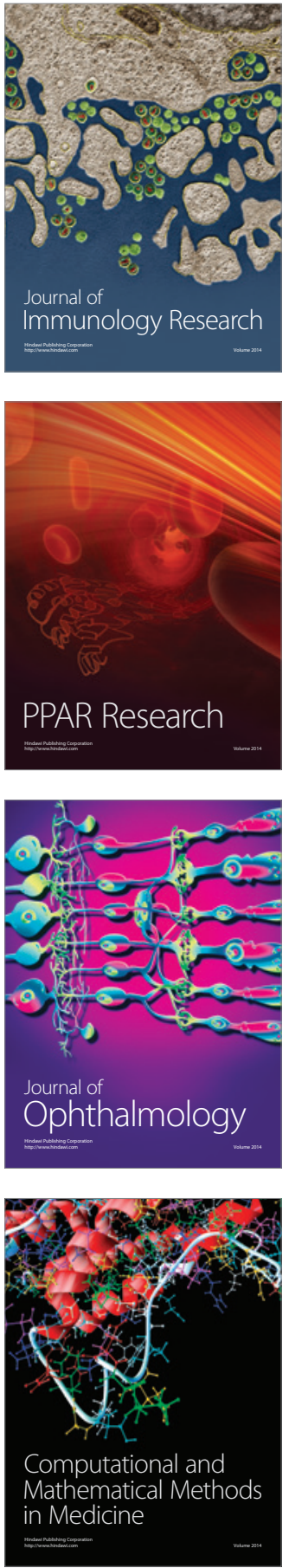

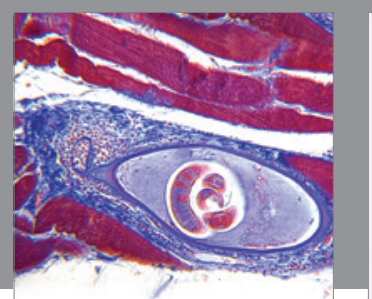

Gastroenterology Research and Practice

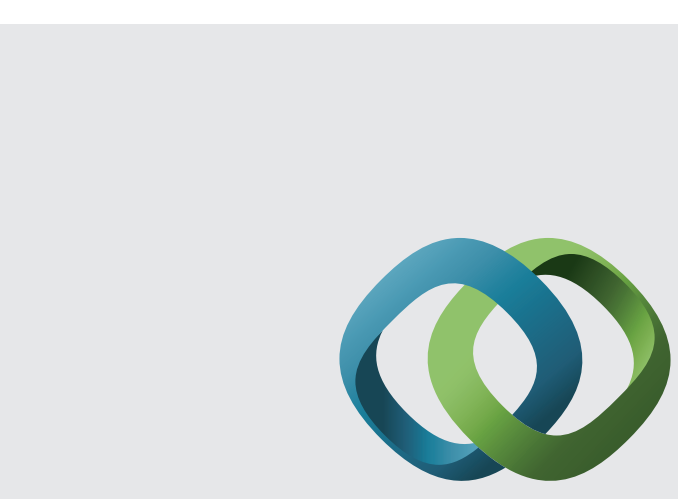

\section{Hindawi}

Submit your manuscripts at

http://www.hindawi.com
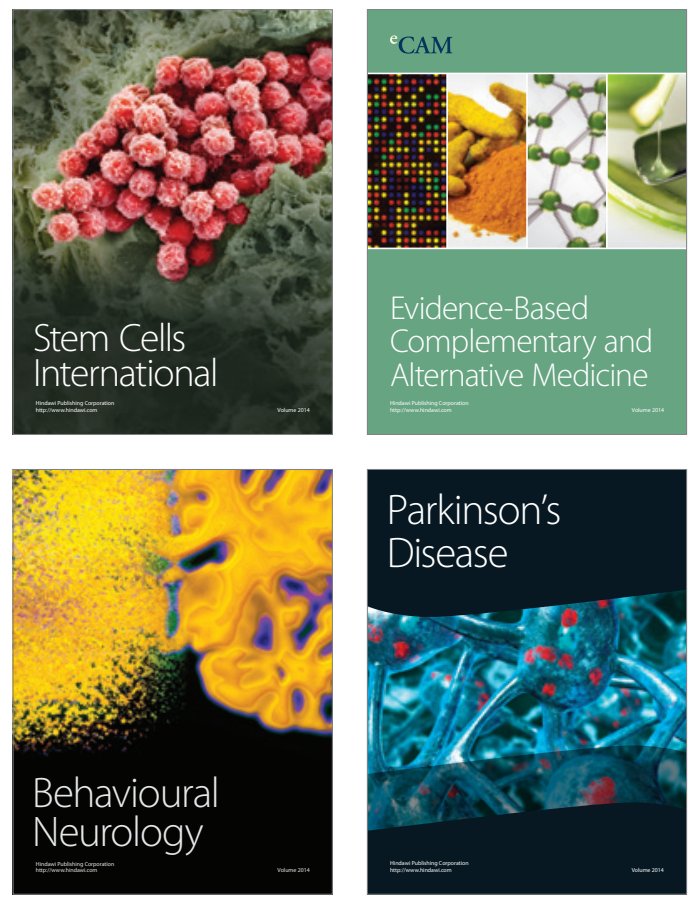
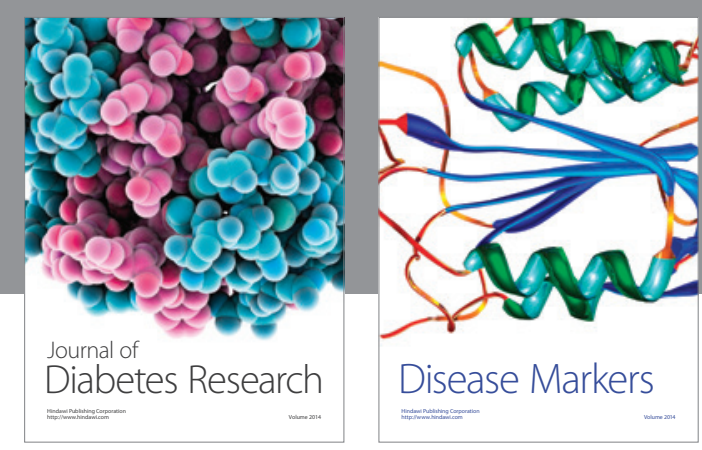

Disease Markers
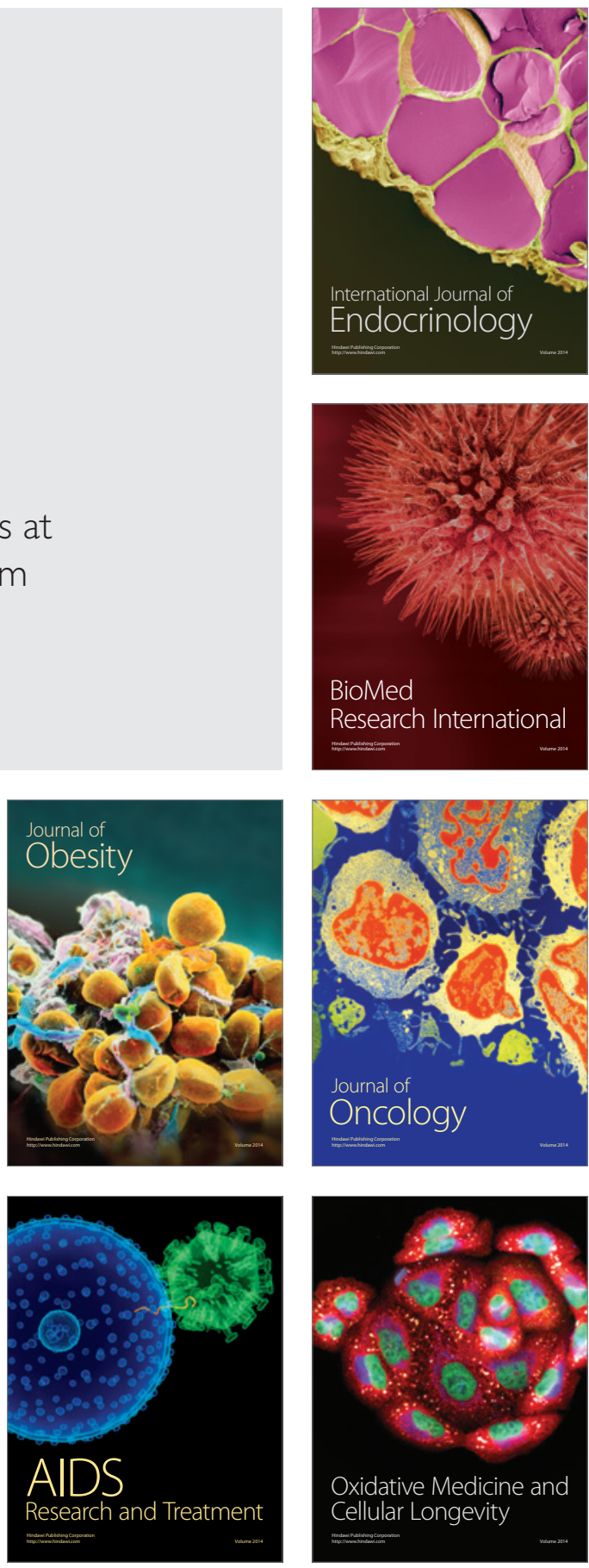